\section{Human rights issues}

The unavailability and inaccessibility of mental healthcare is the most important human rights issue. For those who do receive services, the poor quality of care, the high cost of medication, the generally miserable condition of the hospitals and the lack of attention to safety conditions are prominent concerns. Mental Disability Rights International published in 2004 a very critical report on the conditions of mental hospitals, after which both the ombudsman and the Ministry of Health, with the participation of the Peruvian Psychiatric Association, looked into providers' awareness of human rights and the conditions of the service (Ministry of Health, 2005). The Peruvian Psychiatric Association provided workshops on human rights for psychiatrists and other mental health providers and drafted the Declaration of Cusco, which calls for special concern for patients' rights. However, only the establishment of a national health system and universal health insurance with clear, state-of-the-art and consensual practice guidelines will improve current conditions.

\section{References}

García-Moreno, C., James, H. A. F. M., Ellsber, M., et al (2005) Multicountry Study on Women's Health and Domestic Violence: Initial Results on Prevalences, Health Outcomes and Women's Responses. WHO.

Instituto Especializado de Salud Mental (2002) Estudio epidemiologico metropolitano de salud mental. Informe general. Anales de Salud Mental, 18, 1-2.

Instituto Especializado de Salud Mental (2004) Estudio epidemiológico en salud mental en ayacucho 2003. Anales de Salud Mental, 20, 1-2.

Kendall, R., Matos, L. \& Cabra, M. (2006) Salud mental en el Peru luego de la violencia politica: intervenciones itinerantes. Anales de la Facultad de Medicina, 67, 184-190.

Ministry of Health (2005) Comisión Especial para la supervisión del cumplimiento de los derechos humanos de las personas con enfermedad mental. Informe Final. Ministry of Health.

Perales, A. (1989) Concepto de salud mental: la experiencia peruana. Anales de Salud Mental, 5, 103-110.

Peruvian Truth and Reconciliation Commission (2003) Final Report, Vol. 6. Available at http://www.cverdad.org.pe (last accessed November 2008).

Rondon, M. B. (2003) From Marianism to terrorism: the many faces of violence against women in Latin America. Archives of Women's Mental Health, 6, 157-163.

Rondon M. B. (2006) Salud mental: un problema de salud pública en el Perú. Revista Peruana de Medicina Experimental y Salud Publica, 23 237-238.

\title{
Psychiatric services in Bahrain: past, present and future
}

\section{K. Al-Haddad ${ }^{1}$ and Adel Al-Offi ${ }^{2}$}

1Professor of Psychiatry, Arabian Gulf University, Bahrain; ${ }^{2}$ Consultant Psychiatrist, Ministry of Health, Bahrain

\begin{abstract}
-he Kingdom of Bahrain is an archipelago of 33 islands,
located in the Arabian Gulf, covering $2400 \mathrm{~km}^{2}$. The main island, Manama, is the nation's capital. The total population stands at $742562,62.3 \%$ of whom are local Bahrainis and the remaining $37.7 \%$ expatriates (Central Statistics Organisation Directorate, 1991). Bahrain first entered the historical stage around $3000 \mathrm{BC}$, and for almost 2000 years was the centre of the old Dilmun civilisation (Bibby, 1969). Dilmun was perceived as a sacred land by the Sumerians and Babylonians; it was a burial ground for their dead, and Bahrain has over 100000 burial mounds each containing 200-250 bodies. In the old Babylonian epic of Gilgamesh, which antedates Homer's Iliad, Dilmun is described as a paradise where the worthy enjoy eternal life (Clarke, 1981).
\end{abstract}

\section{Psychiatric services}

Al-Haddad \& Al-Offi (1996) provide a history of Bahraini psychiatric services. Before 1930, no institution cared for psychiatric patients in Bahrain. Left to look after an ailing relative, families often devised their own form of therapy. One of the most common remedies was conducting a Zar ceremony, which was thought to help rid a person of the demons or jin believed to be responsible for mental ailments. Other forms of treatment included reciting verses from the Holy Quran, as well as cautery applied on either the occipital or parietal regions of the head.

In 1930, Charles Belgrave, the English counsel to Bahrain's ruler, suggested the creation of a place for local 'lunatics' which would safely put them under the direct supervision of the Municipal Council. In 1932 a small house was rented in the capital to host 14 patients (12 male, 2 female). The residence was named the 'Mad House' and psychiatric patients were looked after by 'attendants' (who were essentially labourers rather than nursing staff). The Municipal Council continued supervision of the asylum until 1948, when responsibility was transferred to the Department of Health. A report by Dr Snow, chief of the Department of Health at the time, illustrates improvements to the asylum; the building was refurbished and newly painted with pleasant colours, and patients were encouraged to spend more time outside their cells.

In 1964 Dr Butler, an English internist, started to run regular daily psychiatric out-patient clinics, recruited trained psychiatric nurses from India and Lebanon, and introduced the first drug (chlorpromazine) for the treatment of mental illness.

The 1970s witnessed many changes, such as the establishment of a child and adolescent out-patient unit (1975), 
community psychiatric services and a day hospital (1979), and an 88-bed unit for both chronic patients and psychogeriatric patients (1979). In the same year, a liaison service was established with Bahrain's main general hospital, which hosted two general admission units for psychiatry, with a capacity of 48 beds divided equally between males and females. In 1984 a new out-patient complex with lecture halls, teaching facilities and office space was built. In 1987 an alcohol and drug rehabilitation unit was separately developed, with an initial capacity of 17 beds, which had reached 29 beds in 2008 .

\section{Current mental health services}

Today, there is still only one dedicated psychiatric hospital in Bahrain. Private general hospitals employ psychiatrists who mainly work with out-patients, although they do occasionally admit non-psychotic patients, but there are no private beds specifically for psychiatry. The psychiatric hospital has 296 beds for all psychiatric specialties, divided into general psychiatry (114 beds), long-term and rehabilitation (104 beds), psychogeriatrics (10 beds), drug and alcohol rehabilitation (29 beds), adolescents (15 beds), children (12 beds) and forensic psychiatry (12 beds). The same community and day hospital service (in existence since 1979) covers the entire adult and elderly population via three community teams. There are two specialised out-patient clinics, one for anxiety disorders and one for intellectual disability.

The hospital employs 49 full-time psychiatrists, 14 consultants, 11 chief residents, 9 senior residents and 15 residents. There are in total 276 trained psychiatric nurses, 12 occupational therapists, 7 social workers, 4 clinical psychologists, and 2 physiotherapists. There are also 9 consultant-level psychiatrists working in the private sector and a further 2 in the Bahrain Defence Force Hospital. Thus in total there are 60 psychiatrists.

For the past 20 years, psychiatric services have been successfully incorporated within primary care services in Bahrain. Family physicians are also afforded access to psychiatric medications. This is the first such initiative in the Arab world.

\section{Resources}

The Royal College of Psychiatrists' (2002) recommended consultant norms are: 5.4 per 100000 population for general psychiatry, 1 consultant per 10000 for the elderly population, 1.5 per 100000 for children and adolescents, 0.9 per 100000 for substance use, 8 per 1000000 for forensic psychiatry and 1 per 600 general beds for liaison psychiatry. These norms can be applied to Bahrain's population of 742562 . The population above 65 years is 18756 , and so requires 2 psychiatrists, but there is in fact only one consultant in psychogeriatrics. The child and adolescent population has reached 202565, and so requires 3 consultants, which there are now. The general adult population is 521238, requiring 28 consultants but there are only 11 consultants currently working in the field. The registered substance misuse population is 4270 , covered by 3 consultants instead of the recommended 4.6. In forensic psychiatry the need is for nearly 6 consultants, but there is only 1 practising. For liaison psychiatry there are 2 consultants serving 1714 public sector beds, and another 323 beds are covered by psychiatrists working in the private sector; there is a need for a further 3 consultants in that field.

\section{Mental health programme}

A 12-year mental health programme was drafted in 1988, covering Bahrain up to the year 2000 (Al-Haddad, 1988). More than $95 \%$ of the set targets were achieved ahead of time. Accordingly, another plan was drafted in 1997 with an ambitious set of 88 objectives (Al-Haddad, 1997).

\section{Mental health legislation}

Over the past 20 years, many attempts have been made to pass a mental health act in Bahrain. This has still not been achieved. Currently, psychiatrists work within the limited rules related to psychiatry made available in court regulations; some of these date back to when Bahrain was a British protectorate.

\section{Training}

The psychiatric hospital runs a 4-year training programme leading to qualification with the Arab Board of Psychiatry. After qualifying with the Arab Board a further 2 years of clinical training in the UK or USA in general psychiatry or sub-specialties is required.

\section{Research and publications}

Many local psychiatrists are actively involved in research. The establishment of the Medical School as part of the Arabian Gulf University in 1984 was an important catalyst in promoting this. To encourage research, the Ministry of Health stipulates a minimum of two publications for doctors to obtain a consultant post.

\section{Service development}

Progress has been achieved in three key areas:

O In February 2007 the Parliament passed legislation to establish a separate centre for the treatment and rehabilitation of substance misusers. The number of drug users registered in the drug rehabilitation unit is 4270 . A 10 -year follow-up study found a $100 \%$ relapse rate among them (Derbas \& Al-Haddad, 2001). The seroprevalence rate of HIV among drug users was $21.1 \%$ (Al-Haddad et al, 1994).

O The Ministries of Education and Health agreed in 2007 to appoint a psychiatrist with a team of nurses, social workers and psychologists in public school health services to provide counselling and treatment for school children with intellectual disabilities or psychiatric problems.

O One of the unachieved objectives of the 1997 mental health programme was to establish independent specialist teams of psychiatrists, nurses and social workers in the areas of affective disorders, schizophrenia and other sub-specialties. The plan was to establish a separate admission area for each and to encourage research and specialised management. However, a specialist neurosis team and clinic have been established, and have been active since 1998. 
There are four areas of service in which further progress is needed:

O The current day hospital is under the management of the community team and it renders its services to adult populations only. Other categories of psychiatric patients needing such services are the elderly, people with an intellectual disability and adolescents.

O Another challenge is the establishment of sheltered employment for all categories of psychiatric patient. The Bahraini labour law stipulates that $5 \%$ of the working population's employment opportunities should be allocated to people with special needs. In a competitive job market this is difficult to attain, making sheltered employment a challenging but helpful solution.

Both community and day patient facilities still need to be expanded.

O Improvement is still needed in psychiatric services in primary care (by furthering family physicians' training in psychiatry).

\section{References}

Al-Haddad, M. K. (1988) Bahrain Mental Health Programme Till the Year 2000. Ministry of Health.

Al-Haddad, M. K. (1997) Mental and Psychological Health Plan. Ministry of Health.

Al-Haddad, M. K. \& Al-Offi, A. (1996) History of psychiatric services in Bahrain. Journal of the Bahrain Medical Society, 8, 127-131.

Al-Haddad, M. K., Khashaba, A. S., Baig, B. Z., et al (1994) HIV antibodies among intravenous drug users in Bahrain. Journal of Communicable Diseases, 26, 127-132.

Bibby, G. (1969) Looking for Dilmun. New American Library.

Central Statistics Organisation Directorate (1991) Bahrain in Figures. Government of Bahrain.

Clark, A. (1981) The Island of Bahrain. Historical and Archeological Society, Bahrain

Derbas, A. \& Al-Haddad, M. K. (2001) Factors associated with relapse among opiate addicts in Bahrain. Eastern Mediterranean Health Journal, 7, 473-480.

Royal College of Psychiatrists (2002) Model Consultant Job Descriptions and Recommended Norms (occasional paper OP55). RCPsych.

\title{
Sudan's national mental health programme and burden of mental illness
}

\author{
Ehab Ali Sorketti MBBS Sudan MPM (Psychiatry) UM Malaysia
}

Mandag General Hospital, Mandag PO Box 117, Al Baha Region, Kingdom of Saudi Arabia

Suda udan occupies $2500000 \mathrm{~km}^{2}$ in East Africa. It has borders with nine countries, two of which are Arab: Egypt, Libya, Kenya, Uganda, Congo, Chad, the Central African Republic, Ethiopia and Eritrea. Sudan is the largest country in Africa. The heart of the country, in terms of population, lies at the confluence of the Blue and White Niles. The complex of the 'three towns', comprising the three largest cities, Khartoum, Khartoum North and Omdurman, is situated there and contains almost 20\% of the population. The total population of Sudan is about 35.4 million (projected from the 2005 census). The urban population was estimated at 33\% of the total. About 2.2 million are still entirely nomadic. Sudan's peoples are as diverse as its geography. There are 19 major ethnic groups and 597 subgroups.

The Sudanese population is very young, with $43.1 \%$ below the age of 15 years and only $2.7 \%$ above the age of 65 (1994 figures). In 2000, the total adult literacy rate and the female adult literacy rate were estimated at 50\% and $49 \%$ respectively. The crude annual death rate is 11.5 per 1000 population and the crude birth rate is 37.8 per 1000 population (2004). The infant mortality rate is estimated at 68 per 1000 live births, and the under- 5 mortality rate is 104 per
1000 live births. Total life expectancy at birth was 56.6 years in 2000. The maternal mortality rate is estimated at 50.9 per 10000 live births (2000).

Widespread poverty and the erosion of household coping capacities due to war make a large segment of the population vulnerable to food insecurity brought on by crises such as flooding, drought, conflict and displacement. Regional and urban/rural disparities in economic resources have clear implications for health and nutrition as well as service provision.

Psychiatry in Sudan began in the 1950s under the guidance of the late Professor Tigani El Mahi, the father of African psychiatry. He pioneered, among other things, rural services and the open-door policy. His successor, Dr Taha A. Baasher, shouldered the responsibility and further extended services to the periphery.

\section{The national mental health programme}

\section{Targets of the programme}

The guiding principles are: close integration of essential mental healthcare with the general health system, and in 